\title{
Penicillin Resistance in Enterococcus faecalis: Molecular Determinants and Epidemiology
}

\author{
IWONA GAWRYSZEWSKA, WALERIA HRYNIEWICZ and EWA SADOWY* \\ Department of Molecular Microbiology National Medicines Institute, Warsaw, Poland
}

Received 7 December 2011, accepted 4 July 2012

\begin{abstract}
Enterococcus faecalis plays a significant role in hospital-acquired infections (HAIs), and combination of penicillin with aminoglycoside is important in therapy of invasive HAIs. Penicillin resistance in this organism is due to modification of the drug target, penicillin-binding protein (PBP5), its overproduction and expression of $\beta$-lactamase. Although rare, this phenotype is often associated with multi-resistant high-risk enterococcal clonal complexes (HiRECCs), such as CC2 and CC9 which may promote its spread in the near future.
\end{abstract}

Ke y words: Enterococcus faecalis, $\beta$-lactamase, HiRECC, PBP, penicillin, resistance

Enterococci are a part of natural intestinal flora of both human and animals. These Gram-positive bacteria are typically harmless commensals, but in particular conditions they can also cause serious infections. So far, several Enterococcus species have been identified (Hardie and Whiley, 1997), of which two, Enterococcus faecalis and Enterococcus faecium have gained clinical importance. Enterococci have emerged as a serious nosocomial pathogens in the 1990s (Edwards, 2000), and their impact is increasing due to growing numbers of patients at-risk (Sydnor and Perl, 2011). Enterococci were reported as the third most common cause of hospital-associated infections in the United States (Hidron et al., 2008). While the majority (around $80 \%$ ) of enterococcal infections in humans is caused by E. faecalis (Jett et al., 1994; European Centre for Disease Prevention and Control, 2010), the prevalence of E. faecium is currently on the rise (Top et al., 2007; Lester et al., 2008; Hidron et al., 2008). The most serious forms of infection caused by E. faecalis are endocarditis and bloodstream infections; other diseases include urinary tract infections (UTIs) and post-surgery wound infections (Jett et al., 1994); central nervous system and neonatal infections occur with low frequency (Murray, 1998).

Enterococci possess several traits that facilitate dissemination and survival in the hospital settings, and make theirs infections difficult to treat; they are able to grow in the range of $10-45^{\circ} \mathrm{C}$, at $\mathrm{pH} 9.5$, in presence of $6.5 \% \mathrm{NaCl}$ and to survive at $60^{\circ}$ for $30 \mathrm{~min}$ (Sherman,
1937). Enterococci show an intrinsic lack of susceptibility to various antibiotics, including cephalosporins, monobactams, sulphonamides, low concentrations of aminoglycosides, as well as, in the case of E. faecalis, streptogramins and lincosamides. Increasing antibiotic resistance is associated with the capability of these bacteria to acquire and to transfer mobile genetic elements encoding resistance genes (Marothi et al., 2005; Palmer et al., 2010). The resistance to antibiotics can be also developed due to spontaneous mutations. Hospitalassociated strains of E. faecalis often present acquired resistance to antibiotics of several classes such as tetracyclines, quinolones and high-level aminoglycoside resistance (HLAR), while vancomycin-resistant enterococci (VRE) of this species remain rare (Marothi et al., 2005; Hidron et al., 2008). The HLAR phenotype in E. faecalis is of particular concern as the combination of aminoglycoside with penicillin (ampicillin or penicillin $\mathrm{G}$ ) represents a therapy of choice for enterococcal invasive infections (Arias and Murray, 2008). Combination of these two drugs has a synergistic bactericidal effect on enterococci (Moellering and Weinberg, 1971). Normally, the enterococcal cell-wall is poorly permeable for aminoglycosides but these drugs can penetrate to the intracellular target (ribosome) in the presence of the cell-wall synthesis inhibitors as like $\beta$-lactams. In Europe, percentage of HLAR among E. faecalis reach relatively high values - from $30 \%$ to $50 \%$ (European Centre for Disease Prevention and Control, 2010).

* Corresponding author: E. Sadowy, Department of Molecular Microbiology, National Medicines Institute, ul. Chełmska 30/34, 00-725 Warsaw, Poland; phone: +48 2285143 88; fax: +48 2284129 49; e-mail: ewasadowy@cls.edu.pl 
In recent years, we witness an emergence of penicillin-resistant $E$. faecalis isolates in hospital environment. Three mechanisms for penicillin resistance in E. faecalis have been reported, and include (i) production of $\beta$-lactamase which inactivates the drug, (ii) overproduction of the drug target, penicillin-binding proteins (PBPs) and (iii) their decreased affinity for $\beta$-lactams.

\section{Determination and interpretation criteria of penicillin susceptibility in E. faecalis}

According to the guidelines of Clinical and Laboratory Standard Institute (CLSI) determination of E. faecalis susceptibility to penicillin and ampicillin can be carried out with the use of either disc diffusion method or by establishing the minimal inhibitory concentration (MIC) values by an agar or broth dilution methods (Clinical and Laboratory Standard Institute, 2011). Following the CLSI interpretation criteria, strains of E. faecalis can be defined as a susceptible (S), or resistant $(\mathrm{R})$ to penicillin, without an intermediate (I) category (Table I). For the detection of $\beta$-lactamaseproducing strains, the nitrocefin test is recommended (Clinical and Laboratory Standard Institute, 2011). The European Committee on Antimicrobial Susceptibility Testing (EUCAST) provides interpretations of MICs and zone diameters only for ampicillin (Table I) (European Committee on Antimicrobial EUCAST Testing, 2011). Criteria used by CLSI and EUCAST are different, MIC values equal to $8 \mu \mathrm{g} / \mathrm{ml}$ for ampicillin denote susceptible strain according to CLSI but intermediate following the EUCAST criteria.

In addition, the EUCAST provides so-called epidemiological cut-off values (ECOFFs), which separate the wild-type (WT) strains from the strains that exhibit acquired and mutational resistance mechanisms to the drug in question. In the case of E. faecalis, the ECOFF value for penicillin is $16 \mu \mathrm{g} / \mathrm{ml}$, and for ampicillin is $4 \mu \mathrm{g} / \mathrm{ml}$, i.e. the WT strains show MICs lower

Table I

CLSI and EUCAST clinical breakpoints for penicillin and ampicillin for E. faecalis

\begin{tabular}{|l|c|c|c|c|}
\hline \multirow{2}{*}{ CLSI } & \multicolumn{2}{|c|}{$\begin{array}{c}\text { MIC breakpoint } \\
(\mu \mathrm{g} / \mathrm{ml})\end{array}$} & \multicolumn{2}{c|}{$\begin{array}{c}\text { Zone diameter breakpoint } \\
(\mathrm{mm})-\text { disc content } 10 \mu \mathrm{g}\end{array}$} \\
\cline { 2 - 5 } & $\mathrm{S} \leq$ & $\mathrm{R} \geq$ & $\mathrm{S} \geq$ & $\mathrm{R} \leq$ \\
\hline Penicillin & 8 & 16 & 15 & 14 \\
\hline Ampicillin & 8 & 16 & 17 & 16 \\
\hline \multirow{3}{*}{ EUCAST } & \multicolumn{2}{|c|}{$\begin{array}{c}\mathrm{MIC} \text { breakpoint } \\
(\mu \mathrm{g} / \mathrm{ml})\end{array}$} & \multicolumn{2}{c|}{$\begin{array}{c}\text { Zone diameter breakpoint } \\
(\mathrm{mm})-\text { disc content } 2 \mu \mathrm{g}\end{array}$} \\
\cline { 2 - 5 } & $\mathrm{S} \leq$ & $\mathrm{R}>$ & $\mathrm{S} \geq$ & $\mathrm{R}<$ \\
\hline Penicillin & - & - & - & - \\
\hline Ampicillin & 4 & 8 & 10 & 88 \\
\hline
\end{tabular}

than or equal to this values. According to MIC distributions determined by the EUCAST, for most of the E. faecalis strains MIC of penicillin ranges between 2 and $4 \mu \mathrm{g} / \mathrm{ml}$ and MIC of ampicillin ranges between 1 and $2 \mu \mathrm{g} / \mathrm{ml}$ (www.eucast.org/mic_distributions/; $16^{\text {th }}$ November 2011, date last accessed).

\section{Resistance due to the target modification}

Penicillin-binding proteins (PBPs) are produced by almost all bacteria. These membrane proteins are involved in the final stages of peptidoglycan synthesis. Binding $\beta$-lactam antibiotic to PBPs inhibits enzymatic activity of protein and leads to cell growth inhibition or cell death (Lleó et al., 1987). However, certain PBPs show lower affinity to penicillin and because of that, they are responsible for reduced susceptibility to penicillin in a number of Gram-negative and Gram-positive bacteria, including enterococci (Fontana et al., 1983; Canepari et al., 1986; 1987). Low-affinity PBPs replace other PBPs, inhibited by drugs and take over their transpeptidase function (Fontana et al., 1983; 1985).

E. faecalis produces five PBPs, including four highmolecular weight PBPs and one low-molecular weight PBP (Williamson et al., 1983, Duez et al., 2001; Ono et al., 2005). One of these PBPs, designed PBP5, and sometimes named PBP4, is a low-affinity PBP, and its changes and/or overproduction can be related to penicillin resistance. The E. faecalis PBP5 encoded by the genome of V583 strain (Paulsen et al., 2003) is a high-molecular weight protein of about $75 \mathrm{kDa}$ (680aa) and is organized in three distinct domains. The $\mathrm{N}$-terminal hydrophobic domain, about $30 \mathrm{aa}$ long, is responsible for PBP5 anchoring to the cell membrane (Ghuysen et al., 1996; Signoretto and Canepari, 2000). The penicillin-binding domain, with typical penicillinbinding motifs, ${ }_{424} \mathrm{SXXK}_{427},{ }_{482} \mathrm{SDN}_{484}$ and ${ }_{619} \mathrm{KTG}_{621}$, is localized at the $\mathrm{C}$-terminus of the protein (Zapun et al., 2008). These two parts are connected by a central non-penicillin-binding domain of presumable transglycosylase activity proposed by analogy with high-molecular-weight Escherichia coli PBPs (Ghuysen et al., 1996; Signoretto and Canepari, 2000). Non-penicillin-binding domain seems to be essential for the proper folding, stability and the biochemical activity of the penicillin-binding domain, like in E. hirae (Mollerach et al., 1996). This specific structure classifies enterococcal PBP5 in the class B multimodular PBPs (Ghuysen et al., 1996).

PBP5 of E. faecalis is closely related to the other enterococcal low-affinity PBPs described previously (Zorzi et al., 1996). Importance of alterations in PBP5 caused by point mutations for $\beta$-lactam resistance is well-described in E. faecium (Ligozzi et al., 1996; Zorzi 
et al., 1996; Rybkine et al., 1998). Amino acid substitutions in the region between motifs SDN and KTG of the penicillin-binding domain are involved in the resistance to penicillin and ampicillin by decreasing affinity to these drugs (Ligozzi et al., 1993; Fontana et al., 1996; Ligozzi et al., 1996). Similarly, mutations within the PBP5 penicillin-binding domain in E. faecalis result in the decrease of affinity and susceptibility to $\beta$-lactam antibiotics. Such isolates were first detected in Japan in 1998-2002 (Ono et al. 2005). Four clinical isolates with ampicillin MIC values $8-16 \mu \mathrm{g} / \mathrm{ml}$ harbored amino acid alterations of PBP5 at the amino acid positions 520 and 605 (P520S and $\mathrm{Y} 605 \mathrm{H})$, i.e. located in the region between the SDN and KTG motifs of the penicillinbinding domain (Ono et al., 2005). These isolates also showed elevated MICs for imipenem; susceptibility to penicillin was not reported in this study. Mutations in the same amino acid positions were detected in UTI clinical isolates with reduced faropenem susceptibility, also found in Japan (Hiraga et al., 2008). Different kind of modifications was observed in the laboratory mutant strain 56R with high penicillin and ampicillin MIC values equal $128 \mu \mathrm{g} / \mathrm{ml}$ and $64 \mu \mathrm{g} / \mathrm{ml}$, respectively (Signoretto et al., 1994; Signoretto and Canepari, 2000). Comparison of the deduced amino acid sequence of PBP5 from 56R with its counterpart in the JH2-2 susceptible strain revealed that the resistant strain harbors a small frameshift mutation in the non-penicillinbinding domain (the peptide ${ }_{272} \mathrm{AAAQLIGYTG}_{281}$ is replaced by ${ }_{272} \mathrm{ACAINRVYG}_{280}$, resulting in a protein shorter by a single amino acid residue), as well as the $\mathrm{T} / \mathrm{I}$ mutation, immediately adjacent to the $\mathrm{K}$ residue in the SXXK motif (Duez et al., 2001). As the corresponding sequence of the parental susceptible strain 56 was not available, it was not possible to draw reliable conclusion about these changes (Duez et al., 2001). The role of PBP5 for decreased susceptibility to $\beta$-lactams in E. faecalis is further supported by the fact that inactivation of the $p b p 5$ gene in the 56 strain by $\operatorname{Tn} 916$ mutagenesis resulted in 8-fold decrease in the penicillin MIC value of the PBP5-defficient strain (Signoretto and Canepari, 2000).

\section{Resistance mediated by the PBP overproduction}

The overproduction of the drug target appears to be another important mechanism of penicillin resistance in clinical isolates and laboratory mutants of E. faecalis, and was also observed in other enterococcal species such as E. faecium, Enterococcus avium and Enterococcus durans (Fontana et al., 1994; al-Obeid et al., 1990). The exposure of susceptible E. faecalis strains to penicillin led to selection of penicillin-resistant mutants with hyperproduction of PBP5 and this type of resistance was developing both through serial passages on plates containing increasing concentrations of penicillin (al-Obeid et al., 1990; Hodges et al., 1992; Duez et al., 2001) and under continuous penicillin exposure (Hodges et al., 1992). A detailed analysis of the JH2-2r strain with penicillin MIC value of $75 \mu \mathrm{g} / \mathrm{ml}$, overproducing PBP5, and its parental susceptible strain JH2-2 confirmed that both strains harbor identical $p b p 5$ gene (Duez et al., 2001). Apparently increased amount of PBP5 were also observed in E. faecalis from hospital settings in Spain (Cercenado et al., 1996). These two clinical isolates showed MIC values of $64 \mu \mathrm{g} / \mathrm{ml}$ and $32-64 \mu \mathrm{g} / \mathrm{ml}$ for penicillin and ampicillin, respectively, and were isolated independently from two patients with UTI, treated with ampicillin (Cercenado et al., 1996).

The molecular basis of PBP5 overproduction in E. faecalis has not yet been clarified. In E. hirae, synthesis of PBP5 is under the control of the psr gene (PBP5 synthesis repressor), located upstream $p b p 5$, and alteration of $p s r$ by a point mutation or deletion results in the elevated expression of PBP5 (Ligozzi et al., 1993). In E. faecalis, however, no such gene is present in the proximity of to $p b p 5$, and $p s r$-like gene located elsewhere in the genome showed exactly the same sequence in the penicillin-resistant mutant $\mathrm{JH} 2-2 \mathrm{r}$, described above, in comparison to the $\mathrm{JH} 2-2$ parental strain. Moreover, the $p b p 5$ promoter region in both strains was identical (Duez et al., 2001). Therefore, the pathway leading to PBP5 overexpression in E. faecalis remains to be elucidated.

\section{Resistance due to $\beta$-lactamase acquisition}

$\beta$-Lactamase production is another mechanism of resistance penicillin, so far restricted almost exclusively to E.faecalis. The first $\beta$-lactamase producing $(\mathrm{Bla}+)$ enterococcal isolate, $\mathrm{HH} 22$, was detected in Houston, Texas, in 1981 (Murray and MederskiSamaraj, 1983). MIC values for penicillin and ampicillin of $\mathrm{HH} 22$ were above $1000 \mu \mathrm{g} / \mathrm{ml}$, when the high inoculum of $10^{7} \mathrm{CFU} / \mathrm{ml}$ was used (Murray et al., 1986a). Since then, Bla+ enterococci became more prevalent and were isolated from severe infections and nosocomial outbreaks (Murray et al., 1991; 1992; Patterson et al., 1988a; Rhinehart et al., 1990; Wells et al., 1992; Mazzulli et al., 1992). $\beta$-Lactamase from E. faecalis is a typical penicillinase, able to hydrolyze penicillin, ampicillin and ureidopenicillins (e.g. piperacillin), and sensitive to inhibitors such as clavulanic acid (Murray et al., 1986b).

Most likely, enterococci acquired the $\beta$-Lactamase gene from staphylococci (Murray et al., 1986b). The E. faecalis $\mathrm{HH} 22$ carries the bla $\mathrm{Z}$ gene, whose sequence 
is identical to the staphylococcal blaZ genes from the pC1 and pS1 plasmids (Zscheck and Murray, 1991), and from staphylococcal Tn552 transposon (Tomayko et al., 1996). In contrast to the inducible production of large amounts of $\beta$-Lactamase by Staphylococcus aureus, E. faecalis produces the enzyme constitutively on relatively low level (Murray et al., 1986a; Okamoto et al., 1996). Particular enterococcal clones may differ by the presence of the regulatory genes blaR1 (encoding antirepresor) and blaI (encoding repressor) from the bla gene cluster of S. aureus. For example, the $\mathrm{HH} 22$ strain possesses only a part of blaR1 and lacks blaI (Zscheck and Murray, 1993). Even if these genes are present, the $\beta$-lactamase is still produced constitutively. It is possible that blaR1 and blaI contain mutations which make them non-functional or that these regulatory proteins are not active in the enterococcal cell (Zscheck and Murray, 1991; Okamoto et al., 1996; Tomayko et al., 1996).

In E. faecalis, blaZ genes reside either on conjugative plasmids (Murray et al., 1986a, b, Patterson et al., 1988b; 1990; Markowitz et al., 1991), or on bacterial chromosome (Rice et al., 1991; Chow et al., 1993). The blaZ gene in the first described Bla+ isolate $\mathrm{HH} 22$ was shown to be present on the $\sim 70 \mathrm{~kb}$ pheromone-responsive conjugative plasmid pBEM10 that was transferred with a high frequency of $10^{-2}$ (Murray et al., 1988). Efficient conjugative transfer of pheromone-responsive plasmids, specific for enterococci, is due to the unique mechanism of response to so-called sex pheromones, secreted by recipient cells lacking a particular type of plasmid. Stimulated donor cells respond by production of proteins necessary for cell-to-cell contact and subsequent plasmid transmission (Dunny, 1990; Palmer et al., 2010). The pBEM10 plasmid responds to the cAD1 pheromone and uses the same pheromone system as pAD1 (Murray et al., 1988) with which it shares extensive homology (Galli and Wirth, 1991).

The chromosome-located blaZ gene, detected in isolates from Boston, was transferable at low frequency (below $10^{-8}$ ), together with determinants of resistance to a number of other antimicrobials such as erythromycin, gentamicin, mercuric chloride, streptomycin, and tetracycline (Rice et al., 1991). Later on it was shown that bla $\mathrm{Z}$ is associated with a composite $\sim 60 \mathrm{~kb}$ transposon Tn5385 which structure was a subject of several studies. Tn5385 comprises sequences of transposons, such as (1) Tn5381 that carries the tetM gene (Rice et al., 1992), (2) Tn5384, that itself contains $\operatorname{Tn} 4001$ with the aacA$a p h D$ gene (responsible for gentamicin resistance) and a derivative of $\mathrm{Tn} 917$ with the ermB gene (erythromycin resistance determinant) (Rice et al., 1995; Bonafede et al., 1997) and (3) Tn552-like staphylococcal transposon with the blaZ gene and a part of blaR1 (Rice et al., 1996; Bonafede et al., 1997). Additionally, Tn5385 possesses two replication genes of $\mathrm{pAM} \beta 1$, a broadhost range plasmid originally described in E. faecalis, a gene homologous to the putative relaxase gene from small, mobilizable staphylococcal plasmid pS194 and three types if insertions sequences (IS256, IS257, and IS1216), indicating a complex series of co-integration events (Rice and Carias, 1998; Bonafede et al., 1997).

Almost all Bla+ E. faecalis isolates identified so far belong to two clonal complexes, BVE $\left(\mathrm{Bla}^{+} \mathrm{Van}^{\mathrm{r}}\right.$ endocarditis) and ACB (Argentina-Connecticut- $\mathrm{Bla}^{+}$), suggesting a limited number of transfer events of staphylococcal blaZ gene to E. faecalis (Nallapareddy et al., 2005). The BVE clonal complex includes the first Bla+ isolate HH22 (Nallapareddy et al., 2005) and the members of BVE were found spreading in five states (Delaware, Texas, Pennsylvania, Florida, and Virginia) of North America (Murray et al., 1991), including a sevenyear outbreak in a Virginia hospital where they were named the mid-Atlantic clone (Seetulsingh et al., 1996). BVE was also responsible for bloodstream infections in a North Carolina hospital (Murdoch et al., 2002). Representatives of this clone are also often associated with glycopeptide resistance and possess a pathogenicity island (Nallapareddy et al., 2005), thus demonstrating a high pathogenic potential and adaptation to the hospital environment. The ACB clonal complex occurred in hospital outbreaks in Connecticut (Patterson et al., 1991) and Argentina (Murray et al., 1992). Application of multilocus sequence analysis (MLST) to BVE and ACB isolates clustered them into hospital-associated clonal complexes, CC2 and CC9, respectively (RuizGarbajosa et al., 2006). The described above isolates from Boston carrying the Tn5385 transposon also belonged to CC9 (McBride et al. 2007). Both CC2 and CC9 are considered high-risk enterococcal clonal complexes, or HiRECCs (Leavis et al., 2006). Only a single isolate Bla+ from Beirut, Lebanon, did not belong to any of these two HiRECCs (Nallapareddy et al., 2005; Ruiz-Garbajosa et al., 2006). Diversity of blaZ sequence and variable presence of regulatory genes blaR 1 and blaI within the mid-Atlantic/BVE clone suggests that the bla gene cluster has originated from more than one source or the gene cluster has diverged significantly after acquisition (Tomayko et al., 1996).

\section{Current epidemiology of penicillin resistance in E. faecalis}

The resistance to penicillin in clinical isolates of E. faecalis remains a relatively rare phenomenon. A large TEST study collecting isolates in 266 centers in North and Latin America, Asia and Europe in 2004-2006 reported $100 \%$ susceptibility to penicillin and ampicillin among 2701 isolates of E. faecalis (Reinert et al., 
Table II

Susceptibility of E. faecalis to penicillin G and ampicillin in European, Asian, South- and North-American countries

\begin{tabular}{|c|c|c|c|c|c|c|}
\hline $\begin{array}{c}\text { Number } \\
\text { of isolates } \\
\text { tested }\end{array}$ & $\begin{array}{l}\text { Penicillin G/ } \\
\text { ampicillin } \\
\text { resistance [\%] }\end{array}$ & Clinical origin & Location & $\begin{array}{l}\text { Date } \\
\text { of collection }\end{array}$ & $\begin{array}{l}\beta \text {-Lacta- } \\
\text { mase } \\
\text { activity }\end{array}$ & Reference \\
\hline 60 & $8.3 / 3.3$ & $\begin{array}{l}\text { endocarditis, bacteremia, intrabdominal } \\
\text { infections, surgical wound infections }\end{array}$ & $\begin{array}{l}\text { Mexico City, } \\
\text { Mexico }\end{array}$ & $\begin{array}{l}\text { January } 1998 \\
\text { - December } 1999\end{array}$ & negative & $\begin{array}{l}\text { Calderón-Jaimes } \\
\text { et al., } 2003\end{array}$ \\
\hline 75 & $28 / 12$ & rectal swabs (patients from ICUs) & Brasília, Brazil & $\begin{array}{l}\text { January } 2000 \\
\text { - December } 2001\end{array}$ & NT & $\begin{array}{l}\text { Titze-de-Almeida } \\
\text { et al., } 2004\end{array}$ \\
\hline 71 & $27 / 23$ & $\begin{array}{l}\text { bloodstream infections, UTI, surgical } \\
\text { wound infections }\end{array}$ & $\begin{array}{l}\text { Istanbul, } \\
\text { Turkey }\end{array}$ & $\begin{array}{l}\text { January } 2000 \\
\text { - December } 2001\end{array}$ & negative & Oncu et al., 2004 \\
\hline 207 & $12 / 10$ & $\begin{array}{l}\text { bloodstream infections, UTI, surgical } \\
\text { wound infection, catheters }\end{array}$ & $\begin{array}{l}\text { Ankara, } \\
\text { Turkey }\end{array}$ & $\begin{array}{l}\text { October } 2001 \\
\text { - October } 2003\end{array}$ & negative & $\begin{array}{l}\text { Kaçmaz and } \\
\text { Aksoy, } 2005\end{array}$ \\
\hline 287 & $31.4 / 0$ & $\begin{array}{l}\text { bloodstream infections, UTI, surgical } \\
\text { wound infection, catheters }\end{array}$ & $\begin{array}{l}\text { Thessaloniki, } \\
\text { Greece }\end{array}$ & $\begin{array}{l}\text { September } 2003 \\
\text { - December } 2004\end{array}$ & negative & $\begin{array}{l}\text { Metzidie et al., } \\
2006\end{array}$ \\
\hline 277 & $19 / 15$ & UTI & Tehran, Iran & $\begin{array}{l}\text { March } 2002 \\
\text { - April } 2004\end{array}$ & NT & $\begin{array}{l}\text { Jabalameli et al., } \\
2009\end{array}$ \\
\hline 970 & $\mathrm{NT} / 2.0$ & $\begin{array}{l}\text { bloodstream infections, UTI, surgical } \\
\text { wound infections }\end{array}$ & $\begin{array}{l}\text { Cordoba, } \\
\text { Spain }\end{array}$ & $\begin{array}{l}\text { January } 2004 \\
\text { - August } 2005\end{array}$ & NT & $\begin{array}{l}\text { Causse et al., } \\
2006\end{array}$ \\
\hline 625 & $\mathrm{NT} / 1.1$ & $\begin{array}{l}\text { bloodstream infections, skin \& soft } \\
\text { tissue infections }\end{array}$ & $\begin{array}{l}\text { Brasil } \\
\text { (4 centers) }\end{array}$ & $2005-2009$ & NT & Gales et al., 2009 \\
\hline 67 & $38.8 / 4.8$ & UTI & $\begin{array}{l}\text { Istanbul, } \\
\text { Turkey }\end{array}$ & $\begin{array}{l}\text { January } \\
\text { - July } 2008\end{array}$ & NT & Butcu et al., 2011 \\
\hline 282 & $22.3 / 1.4$ & $\begin{array}{l}\text { bloodstream infections, UTI, surgical } \\
\text { wound infection, catheters }\end{array}$ & $\begin{array}{l}\text { Uberaba, } \\
\text { Brasil }\end{array}$ & 2006-2009 & negative & $\begin{array}{l}\text { Conceição et al., } \\
2011\end{array}$ \\
\hline
\end{tabular}

NT, not tested

2007). Analysis of the Surveillance Network databases, collecting susceptibility data of predominant ICU pathogens during 2000-2002 from 650 hospitals in Europe (France, Germany and Italy), Canada, and the US revealed ampicillin resistance ranging from $0.2 \%$ (France) to $4.7 \%$ (Italy) among 7865 isolates of E. faecalis (Jones et al., 2004). Some of national studies recently report much higher ratios of penicillin resistance (Table II). In general, little is known about clonal relationships of current penicillin-resistant E. faecalis. Recently, twenty E. faecalis isolates from bloodstream infections from seven hospitals in Denmark collected in 2007 displaying reduced susceptibility to penicillin (MIC $>16 \mu \mathrm{g} / \mathrm{ml}$ by the Etest method and $4-8 \mu \mathrm{g} / \mathrm{ml}$ by the broth microdillution method) and full ampicillin susceptibility were reported. Most of these isolates (17) belonged to the same sequence type ST6 of CC2. The mechanism underlying this phenotype was not studied (Guardabassi et al., 2010). Pulsed-field gel electrophoresis (PFGE) analysis of 90 penicillin-resistant but ampicillin-susceptible isolates from Greece revealed that the majority (52) of them belonged to a single genotype while the remaining 38 isolates were grouped in five genotypes (Metzidie et al., 2006). None of these isolates produced $\beta$-lactamase (Table II).

\section{Conclusions and perspectives}

Penicillin and ampicillin play an important role in the treatment of serious infections caused by E. faecalis and the development of resistance to these drugs implies serious clinical problems, especially as it excludes a synergistic bactericidal effect of $\beta$-lactams in combination with aminoglycosides. The first cases of ampicillin-resistant E. faecium (AREfm) were identified in the early 1980s. AREfm isolates have emerged as a causative agent of nosocomial infections and outbreaks (Coudron et al., 1984). Generally, ampicillin resistance has become a typical trait for hospitalassociated strains of E. faecium, in particular of CC17, a HiRECC found in hospitals all over the world. One of the first steps of hospital-adaptation of CC17 was acquisition of ampicillin resistance (Leavis et al., 2006; Galloway-Peña et al., 2009). Although still rare, penicillin resistance can be also acquired by E. faecalis via various mechanisms and is often associated with HiRECCs circulating in hospitals. Moreover, the determinants of the resistance, such as $\beta$-lactamase genes, have a potential to be transferred to susceptible strains due to their localization on pheromone-responsive plasmids and within conjugative transposons. These elements 
contribute to the resistance spread among different species of bacteria, such as acquisition of $\beta$-lactamase gene from staphylococci by E. faecalis (Murray et al., 1986b) and subsequent transmission of the trait to E. faecium (Coudron et al., 1992). Also chromosomal determinant, $p b p 5$, may disseminate in the population of E. faecalis due to frequent recombination in this species (RuizGarbajosa et al., 2006). It is necessary to observe phenomenon of penicillin-resistance among E. faecalis.

\section{Acknowledgements}

This work was partially done in the frame of grant ACE from the European Union $6^{\text {th }}$ Framework Program under contract LSHECT-2007-037410, together with a complementary founding from the Ministry of Science and Higher Education, Poland (decision 937/6. PR UE/2009/7).

\section{Literatura}

al-Obeid S., L. Gutmann and R. Williamson. 1990. Modification of penicillin-binding proteins of penicillin-resistant mutants of different species of enterococci. J. Antimicrob. Chemother. 26: 613-618. Arias C.A. and B.E. Murray. 2008. Emergence and management of drug-resistant enterococcal infections. Expert Rev. Anti. Infect. Ther. 6: 637-655

Bonafede M.E., L.L. Carias and L.B. Rice. 1997. Enterococcal transposon Tn5384: evolution of a composite transposon through cointegration of enterococcal and staphylococcal plasmids. Antimicrob. Agents Chemother. 41: 1854-1858.

Butcu M., S.S. Akcay, A.S. Inan, S. Aksaray, D.O. Engin and G. Calisici. 2011. In vitro susceptibility of enterococci strains isolated from urine samples to fosfomycin and other antibiotics. J. Infect. Chemother. 17: 575-578.

Calderón-Jaimes E., J.L. Arredondo-García, F. Aguilar-Ituarte, P. García-Roca. 2003. In vitro antimicrobial susceptibility in clinical isolates of Enterococcus species. Salud Pública Méx 45: 96-101. Canepari P., M.M. Lleò, G. Cornaglia, R. Fontana and G. Satta. 1986. In Streptococcus faecium penicillin-binding protein 5 alone is sufficient for growth at sub-maximal but not at maximal rate. J. Gen. Microbiol. 132: 625-631.

Canepari P., M.M. Lleò, R. Fontana and G. Satta. 1987. Streptococcus faecium mutants that are temperature sensitive for cell growth and show alterations in penicillin-binding proteins. J. Bacteriol. 169: 2432-2439.

Causse M., F. Franco-Alvarez de Luna, A.D. García-Mayorgas, F.C. Rodríguez and M. Casal. 2006. Antimicrobial susceptibility of Enterococcus faecalis isolated from patients in Córdoba (Spain). Rev. Esp. Quimioter. 19: 140-143.

Cercenado E., M.F. Vicente, M.D. Díaz, C. Sánchez-Carrillo and M. Sánchez-Rubiales. 1996. Characterization of clinical isolates of beta-lactamase-negative, highly ampicillin-resistant Enterococcus faecalis. Antimicrob. Agents Chemother. 40: 2420-2422.

Chow J.W., M.B. Perri, L.A. Thal and M.J. Zervos. 1993. Mobilization of the penicillinase gene in Enterococcus faecalis. Antimicrob. Agents Chemother. 37: 1187-1189.

Clinical and Laboratory Standards Institute. 2011. Performance Standards for Antimicrobial Susceptibility Testing; Twenty-First Informational Supplement. M100-S21. Vol. 31 No. 1.

Conceição N., C. Oliveira Cda, P.R. Silva, B.G. Avila and A.G. Oliveira. 2011. Trends in antimicrobial resistance among clinical isolates of enterococci in a Brazilian tertiary hospital: a 4-year study. Rev. Soc. Bras. Med. Trop. 44: 177-181.
Coudron P.E., S.M. Markowitz and E.S. Wong. 1992. Isolation of a beta-lactamase-producing, aminoglycoside-resistant strain of Enterococcus faecium. Antimicrob. Agents Chemother. 36: 1125-1126. Coudron P.E., C.G. Mayhall, R.R. Facklam, A.C. Spadora, V.A. Lamb, M.R. Lybrand and H.P. Dalton. 1984. Streptococcus faecium outbreak in a neonatal intensive care unit. J. Clin. Microbiol. 20: 1044-1048.

Duez C., W. Zorzi, F. Sapunaric, A. Amoroso, I. Thamm and J. Coyette. 2001. The penicillin resistance of Enterococcus faecalis $\mathrm{JH} 2-2 \mathrm{r}$ results from an overproduction of the low-affinity penicillinbinding protein PBP4 and does not involve a psr-like gene. Microbiology 147: 2561-2569.

Dunny G.M. 1990. Genetic functions and cell-cell interactions in the pheromone-inducible plasmid transfer system of Enterococcus faecalis. Mol. Microbiol. 4: 689-696.

Edwards D.D. 2000. Enterococci attract attention of concerned microbiologists. ASM News 66: 540-545.

European Centre for Disease Prevention and Control. 2010. Antimicrobial resistance surveillance in Europe 2009. Annual Report of the European Antimicrobial Resistance Surveillance Network (EARS-Net). Stockholm. ECDC.

European Committee on Antimicrobial Susceptibility Testing. 2011. Breakpoint tables for interpretation of MICs and zone diameters. Version 1.3.

Fontana R., M. Aldegheri, M. Ligozzi, H. Lopez, A. Sucari and G. Satta. 1994. Overproduction of a low-affinity penicillin-binding protein and high level ampicillin resistance in Enterococcus faecium. Antimicrob. Agents Chemother. 38: 1980-1983.

Fontana R., R. Cerini, P. Longoni, A. Grossato and P. Canepari. 1983. Identification of a streptococcal penicillin-binding protein that reacts very slowly with penicillin. J. Bacteriol. 155: 1343-1350. Fontana R., A. Grossato, L. Rossi, Y.R. Cheng and Satta G. 1985. Transition from resistance to hypersusceptibility to beta-lactam antibiotics associated with loss of a low-affinity penicillin-binding protein in a Streptococcus faecium mutant highly resistant to penicillin. Antimicrob. Agents Chemother. 28: 678-683.

Fontana R., M. Ligozzi, F. Pittaluga, and G. Satta. 1996. Intrinsic penicillin resistance in enterococci. Microb. Drug Resist. 2: 209-213. Gales A.C., H.S. Sader, J. Ribeiro, C. Zoccoli, A. Barth and A.C. Pignatari. 2009. Antimicrobial susceptibility of gram-positive bacteria isolated in Brazilian hospitals participating in the SENTRY Program (2005-2008). Braz. J. Infect. Dis. 13: 90-98.

Galli D. and R. Wirth. 1991. Comparative analysis of Enterococcus faecalis sex pheromone plasmids identifies a single homologous DNA region which codes for aggregation substance. J. Bacteriol. 173: 3029-3033.

Galloway-Peña J.R., S.R. Nallapareddy, C.A. Arias, G.M. Eliopoulos and B.E. Murray. 2009. Analysis of clonality and antibiotic resistance among early clinical isolates of Enterococcus faecium in the United States. J. Infect. Dis. 200: 1566-1573.

Ghuysen J.M., P. Charlier, J. Coyette, C. Duez, E. Fonzé, C. Fraipont, C. Goffin, B. Joris and M. Nguyen-Distèche. 1996. Penicillin and beyond: evolution, protein fold, multimodular polypeptides, and multiprotein complexes. Microb. Drug Resist. 2: 163-175.

Grayson M.L., G.M. Eliopoulos, C.B. Wennersten, K.L. Ruoff, P.C. De Girolami, M.J. Ferraro and R.C. Moellering Jr. 1991. Increasing resistance to beta-lactam antibiotics among clinical isolates of Enterococcus faecium: a 22-year review at one institution. Antimicrob. Agents Chemother. 35: 2180-2184.

Guardabassi L., J. Larsen, R. Skov and H.C. Schønheyder. 2010. Gentamicin-resistant Enterococcus faecalis sequence type 6 with reduced penicillin susceptibility: diagnostic and therapeutic implications. J. Clin. Microbiol. 48: 3820-3821.

Hardie J.M. and R.A. Whiley. 1997. Classification and overview of the genera Streptococcus and Enterococcus. Soc. Appl. Bacteriol. Symp. Ser. 26: 1S-11S. 
Hidron A.I., J.R. Edwards, J. Patel, T.C. Horan, D.M. Sievert, D.A. Pollock, S.K. Fridkin, National Healthcare Safety Network Team; Participating National Healthcare Safety Network Facilities. 2008. NHSN annual update: antimicrobial-resistant pathogens associated with healthcare-associated infections: annual summary of data reported to the National Healthcare Safety Network at the Centers for Disease Control and Prevention, 2006-2007. Infect Control Hosp Epidemiol 29: 996-1011. Erratum in: Infect. Control. Hosp. Epidemiol. 2009. 30: 107.

Hiraga N., T. Muratani, S. Naito and T. Matsumoto. 2008. Genetic analysis of faropenem-resistant Enterococcus faecalis in urinary isolates. J. Antibiot. 61: 213-221.

Hodges T.L., S. Zighelboim-Daum, G.M. Eliopoulos, C. Wennersten and R.C. Moellering Jr. 1992. Antimicrobial susceptibility changes in Enterococcus faecalis following various penicillin exposure regimens. Antimicrob. Agents Chemother. 36: 121-125.

Jabalameli F., M. Emaneini, S. Shahsavan, H. Sedaghat, Z. Abdolmaliki and M. Aligholi. 2009. Evaluation of antimicrobial susceptibility patterns of enterococci isolated from patients in Tehran University of Medical Sciences Teaching Hospitals. Acta Med. Iran. 47: 325-328.

Jett B.D., M.M. Huycke and M.S. Gilmore. 1994. Virulence of enterococci. Clin. Microbiol. Rev. 7: 462-478.

Jones M.E., D.C. Draghi, C. Thornsberry, J.A. Karlowsky, D.F. Sahm and R.P. Wenzel. 2004. Emerging resistance among bacterial pathogens in the intensive care unit a European and North American Surveillance study (2000-2002). Ann. Clin. Microbiol. Antimicrob. 3: 14.

Kaçmaz B. and A. Aksoy. 2005. Antimicrobial resistance of enterococci in Turkey. Int. J. Antimicrob. Agents 25: 535-538.

Leavis H.L., M.J. Bonten and R.J. Willems. 2006. Identification of high-risk enterococcal clonal complexes: global dispersion and antibiotic resistance. Curr. Opin. Microbiol. 9: 454-460.

Lester C.H., D. Sandvang, S.S. Olsen, H.C. Schønheyder, J.O. Jarløv, J. Bangsborg, D.S. Hansen, T.G. Jensen, N. Frimodt-Møller, A.M. Hammerum, DANRES Study Group. 2008. Emergence of ampicillin-resistant Enterococcus faecium in Danish hospitals. J. Antimicrob. Chemother. 62: 1203-1206.

Ligozzi, M., F. Pittaluga and R. Fontana. 1993. Identification of a genetic element ( $p s r)$ which negatively controls expression of Enterococcus hirae penicillin-binding protein 5. J. Bacteriol. 175: 2046-2051.

Ligozzi, M., F. Pittaluga and R. Fontana. 1996. Modification of penicillin binding protein 5 associated with high-level ampicillin resistance in Enterococcus faecium. Antimicrob. Agents Chemother. 40: 354-357.

Lleó M.M., P. Canepari, G. Cornaglia, R. Fontana and G. Satta. 1987. Bacteriostatic and bactericidal activities of beta-lactams against Streptococcus (Enterococcus) faecium are associated with saturation of different penicillin-binding proteins. Antimicrob. Agents Chemother. 31: 1618-1626.

Markowitz S.M., V.D. Wells, D.S. Williams, C.G. Stuart, P.E. Coudron and E.S. Wong. 1991. Antimicrobial susceptibility and molecular epidemiology of beta-lactamase-producing, aminoglycoside-resistant isolates of Enterococcus faecalis. Antimicrob. Agents Chemother. 35: 1075-1080.

Marothi Y.A., H. Agnihotri and D. Dubey. 2005. Enterococcal resistance - an overview. Indian J. Med. Microbiol. 23: 214-219.

Mazzulli T., S.M. King and S.E. Richardson SE. 1992. Bacteremia due to beta-lactamase-producing Enterococcus faecalis with highlevel resistance to gentamicin in a child with Wiskott-Aldrich syndrome. Clin. Infect. Dis. 14: 780-781.

McBride S.M., V.A. Fischetti, D.J. Leblanc, R.C. Moellering Jr and M.S. Gilmore. 2007. Genetic diversity among Enterococcus faecalis. PLOS ONE 2: e582.
Metzidie E., E.N. Manolis, S. Pournaras, D. Sofianou and A. Tsakris. 2006. Spread of an unusual penicillin- and imipenemresistant but ampicillin-susceptible phenotype among Enterococcus faecalis clinical isolates. J. Antimicrob. Chemother. 57: 158-160.

Moellering R.C. Jr and A.N. Weinberg. 1971. Studies on antibiotic synergism against enterococci. II. Effect of various antibiotics on the uptake of $14 \mathrm{C}$-labeled streptomycin by enterococci. J. Clin. Invest. 50: 2580-2584.

Mollerach M.E., P. Partoune, J. Coyette and J.M. Ghuysen. 1996. Importance of the E-46-D-160 polypeptide segment of the nonpenicillin-binding module for the folding of the low-affinity, multimodular class B penicillin-binding protein 5 of Enterococus hirae. J. Bacteriol. 178: 1774-1775.

Murdoch D.R., S. Mirrett, L.J. Harrell, J.S. Monahan and L.B. Reller. 2002. Sequential emergence of antibiotic resistance in enterococcal bloodstream isolates over 25 years. Antimicrob. Agents Chemother. 46: 3676-3678.

Murray B.E. 1998. Diversity among multidrug-resistant enterococci. Emerging Infect. Dis. 4: 37-47.

Murray B.E. and B. Mederski-Samaraj. 1983. Transferable betalactamase. A new mechanism for in vitro penicillin resistance in Streptococcus faecalis. J. Clin. Invest. 72: 1168-1171.

Murray B.E., F.Y. An and D.B. Clewell. 1988. Plasmids and pheromone response of the beta-lactamase producer Streptococcus (Enterococcus) faecalis $\mathrm{HH} 22$. Antimicrob. Agents Chemother. 32: 547-551. Murray B.E., D.A. Church, A. Wanger, K. Zscheck, M.E. Levison, M.J. Ingerman, E. Abrutyn and B. Mederski-Samoraj. 1986a. Comparison of two beta-lactamase-producing strains of Streptococcus faecalis. Antimicrob. Agents Chemother. 30: 861-864.

Murray B.E., B. Mederski-Samoraj, S.K. Foster, J.L. Brunton and P. Harford. 1986b. In vitro studies of plasmid mediated penicillinase from Streptococcus faecalis suggest a staphylococcal origin. J. Clin. Invest. 77: 289-293.

Murray B.E., H.A. Lopardo, E.A. Rubeglio, M. Frosolono and K.V, Singh. 1992. Intrahospital spread of a single gentamicinresistant, beta-lactamase-producing strain of Enterococcus faecalis in Argentina. Antimicrob. Agents Chemother. 36: 230-232.

Murray B.E., K.V. Singh, S.M. Markowitz, H.A. Lopardo, J.E. Patterson, M.J. Zervos E. Rubeglio, G.M. Eliopoulos, L.B. Rice, F.W. Goldstein and others. 1991. Evidence for clonal spread of a single strain of beta-lactamase-producing Enterococcus (Streptococcus) faecalis to six hospitals in five states. J. Infect. Dis. 163: 780-785. Nallapareddy S.R., H. Wenxiang, G.M. Weinstock and B.E. Murray. 2005. Molecular characterization of a widespread, pathogenic, and antibiotic resistance-receptive Enterococcus faecalis lineage and dissemination of its putative pathogenicity island. J. Bacteriol. 187: 5709-5718.

Okamoto R., T. Okubo and M. Inoue. 1996. Detection of genes regulating beta-lactamase production in Enterococcus faecalis and Staphylococcus aureus. Antimicrob. Agents Chemother. 40: 2550-2554. Oncu S., M. Punar and H. Eraksoy. 2004. Susceptibility patterns of enterococci causing infections. Tohoku J. Exp. Med. 202: 23-29. Ono S., T. Muratani and T. Matsumoto. 2005. Mechanisms of resistance to imipenem and ampicillin in Enterococcus faecalis. Antimicrob. Agents Chemother. 49: 2954-2958.

Palmer K.L., V.N, Kos and M.S. Gilmore. 2010. Horizontal gene transfer and the genomics of enterococcal antibiotic resistance. Curr. Opin. Microbiol. 13: 632-639.

Patterson J.E., S.M. Colodny and M.J. Zervos. 1988a. Serious infection due to beta-lactamase-producing Streptococcus faecalis with high-level resistance to gentamicin. J. Infect. Dis. 158: 1144-1145. Patterson J.E., B.L. Masecar, C.A. Kauffman, D.R. Schaberg, W.J. Hierholzer Jr and M.J. Zervos. 1988b. Gentamicin resistance plasmids of enterococci from diverse geographic areas are heterogeneous. J. Infect. Dis. 158: 212-216. 
Patterson J.E., K.V. Singh and B.E. Murray. 1991. Epidemiology of an endemic strain of beta-lactamase-producing Enterococcus faecalis. J. Clin. Microbiol. 29: 2513-2516.

Patterson, J. E., A. Wanger, K.K. Zscheck, M.J. Zervos and B.E. Murray. 1990. Molecular epidemiology of $\beta$-lactamase producing enterococci. Antimicrob. Agents Chemother. 34: 302-305.

Paulsen I.T., L. Banerjei, G.S. Myers, K.E. Nelson, R. Seshadri, T.D. Read, D.E. Fouts, J.A. Eisen, S.R. Gill, J.F. Heidelberg and others. 2003. Role of mobile DNA in the evolution of vancomycin resistant Enterococcus faecalis. Science 299: 2071-2074.

Reinert R.R., D.E. Low, F. Rossi, X. Zhang, C. Wattal and M.J. Dowzicky. 2007. Antimicrobial susceptibility among organisms from the Asia/Pacific Rim, Europe and Latin and North America collected as part of TEST and the in vitro activity of tigecycline. J. Antimicrob. Chemother. 60: 1018-1029.

Rhinehart E., N.E. Smith, C. Wennersten, E. Gorss, J. Freeman, G.M. Eliopoulos, R.C. Moellering Jr. and D.A. Goldmann. 1990. Rapid dissemination of $\beta$-lactamase-producing, aminoglycosideresistant Enterococcus faecalis among patients and staff on an infanttoddler surgical ward. N. Engl. J. Med. 323: 1814-1818.

Rice L.B. and L.L. Carias. 1998. Transfer of Tn5385, a composite, multiresistance chromosomal element from Enterococcus faecalis. J. Bacteriol. 180: 714-721.

Rice, L. B., L. L. Carias, and S. H. Marshall. 1995. Tn5384, a composite enterococcal mobile element conferring resistance to erythromycin and gentamicin whose ends are directly repeated copies of IS256. Antimicrob. Agents Chemother. 39: 1147-1153.

Rice L.B., L.L. Carias, S.H. Marshall and M.E. Bonafede. 1996. Sequences found on staphylococcal beta-lactamase plasmids integrated into the chromosome of Enterococcus faecalis CH116. Plasmid 35: 81-90.

Rice L.B., G.M. Eliopoulos, C. Wennersten, D. Goldmann, G.A. Jacoby and R.C. Moellering Jr. 1991. Chromosomally mediated beta-lactamase production and gentamicin resistance in Enterococcus faecalis. Antimicrob. Agents Chemother. 35: 272-276.

Rice, L.B., S.H. Marshall, and L.L. Carias. 1992. Tn5381, a conjugative transposon identifiable as a circular form in Enterococcus faecalis. J. Bacteriol. 174: 7308-7315.

Ruiz-Garbajosa P., M.J. Bonten, D.A. Robinson, J. Top, S.R. Nallapareddy, C. Torres, C.M. Coque, R. Cantón, F. Baquero, B.E. Murray and others. 2006. Multilocus sequence typing scheme for Enterococcus faecalis reveals hospital-adapted genetic complexes in a background of high rates of recombination. J. Clin. Microbiol. 44: 2220-2228.

Rybkine T., J.L. Mainardi, W. Sougakoff, E. Collatz and Gutmann. 1998. Penicillin-binding protein 5 sequence alterations in clinical isolates of Enterococcus faecium with different levels of beta-lactam resistance. J. Infect. Dis. 178: 159-163.

Seetulsingh P.S., J.F. Tomayko, P.E. Coudron, S.M. Markowitz, C. Skinner, K.V. Singh and B.E. Murray. 1996. Chromosomal DNA restriction endonuclease digestion patterns of beta-lactamase-producing Enterococcus faecalis isolates collected from a single hospital over a 7-year period. J. Clin. Microbiol. 34: 1892-1896.

Sherman J.M. 1937. The streptococci. Bacteriol Rev 1: 3-97.

Signoretto, C., and P. Canepari. 2000. Paradoxical effect of inserting, in Enterococcus faecalis penicillin-binding protein 5, an amino acid box responsible for low affinity for penicillin in Enterococcus faecium. Arch. Microbiol. 173: 213-219.

Signoretto C., M. Boaretti and P. Canepari. 1994. Cloning, sequencing and expression in Escherichia coli of the low-affinity penicillin binding protein of Enterococcus faecalis. FEMS Microbiol. Lett. 123: 99-106.

Sydnor E.R. and T.M. Perl. 2011. Hospital epidemiology and infection control in acute-care settings. Clin. Microbiol. Rev. 24: 141-173. Titze-de-Almeida R., M.R. Filho, C.A. Nogueira, I.P. Rodrigues, J.E. Filho, R.S. do Nascimento, R.F. Ferreira, L.M.P. Moraes, H. Boelens, A. van Belkum and others. 2004. Molecular epidemiology and antimicrobial susceptibility of Enterococci recovered from Brazilian intensive care units. Braz. J. Infect. Dis. 8: 197-205. Tomayko J.F., K.K. Zscheck, K.V. Singh, B.E. Murray. 1996. Comparison of the beta-lactamase gene cluster in clonally distinct strains of Enterococcus faecalis. Antimicrob. Agents Chemother. 40: $1170-1174$

Top J., R. Willems, H. Blok, M. de Regt, K. Jalink, A. Troelstra, B. Goorhuis and M. Bonten. 2007. Ecological replacement of Enterococcus faecalis by multiresistant clonal complex 17 Enterococcus faecium. Clin. Microbiol. Infect. 13: 316-319.

Wells V.D., E.S. Wong, B.E. Murray, P.E. Coudron, D.S Williams and S.M. Markowitz. 1992. Infections due to beta-lactamase-producing, high-level gentamicin-resistant Enterococcus faecalis. Ann. Intern. Med. 116: 285-292.

Williamson R., S.B. Calderwood, R.C. Moellering Jr. and A. Tomasz. 1983. Studies on the mechanism of intrinsic resistance to beta-lactam antibiotics in group D streptococci. J. Gen. Microbiol. 129: 813-822.

Zapun, A., C. Contreras-Martel and T. Vernet. 2008. Penicillinbinding proteins and beta-lactam resistance. FEMS Microbiol. Rev. 32: 361-385.

Zorzi W., X.Y. Zhou, O. Dardenne, J. Lamotte, D. Raze, J. Pierre, L. Gutmann and J. Coyette. 1996. Structure of the low-affinity penicillin-binding protein $5 \mathrm{PBP} 5 \mathrm{fm}$ in wild-type and highly penicillinresistant strains of Enterococcus faecium. J. Bacteriol. 178: 4948-4957.

Zscheck K.K. and B.E. Murray. 1991. Nucleotide sequence of the beta-lactamase gene from Enterococcus faecalis $\mathrm{HH} 22$ and its similarity to staphylococcal beta-lactamase genes. Antimicrob. Agents Chemother. 35(9):1736-40.

Zscheck K.K. and B.E. Murray. 1993. Genes involved in the regulation of beta-lactamase production in enterococci and staphylococci. Antimicrob. Agents Chemother. 37: 1966-1970. 